\title{
The Basics of Research Article Licensing
}

\author{
Raghav Yelamanchi $^{1}{ }^{\circledR} \cdot$ Nikhil Gupta $^{1} \cdot$ Binita Goswami $^{2} \cdot$ C. K. Durga ${ }^{1}$
}

Received: 27 April 2021 / Accepted: 15 November 2021/Published online: 21 November 2021

(c) Association of Surgeons of India 2021

\section{Dear Editor-in-Chief,}

Research articles published in the journals are subjected to copyright and various licensing agreements. Most of the authors are not aware of what these licensing agreements mean and simply agree to the terms and conditions during the publication process. Also, they may use the data and material from the already published articles without due acknowledgements and permissions leading to various legal troubles $[1,2]$. This article summarizes the basics of research article licensing that all authors should know (Table 1).

More and more journals are publishing their content under open access subject to licensing agreements. The most common licensing used is the one created by CC (Creative Commons), a non-profit organization in the USA established in 2001. These licenses allow researchers to use material from the published articles under specified conditions without the need for obtaining specific permissions from the original authors [3].

CCO (Public Domain): This licensing allows the free distribution and usage of data across the world without any restrictions and attributions.

CC-BY (Attribution): This license allows usage and distribution of data, modifications, and making new derivatives from previously published articles after giving credits to the original authors of the article as specified by them. This is one of the most commonly used licensing agreements in daily practice by open access journals.

CC-BY NC (Attribution Non-Commercial): This license allows researchers to distribute and use data from the original source in the native or altered form provided

Raghav Yelamanchi

raghavyelamanchi@gmail.com

1 Department of Surgery, Ward 17, Atal Bihari Vajpayee Institute of Medical Sciences and Dr. Ram Manohar Lohia Hospital, New Delhi Pin-110001, India

2 Department of Biochemistry, Maulana Azad Medical College, New Delhi Pin-110006, India it is distributed free of cost for non-commercial purposes. Any profit making is strictly prohibited.

CC-BY SA (Attribution Share-Alike): This license requires researchers developing new products from the original research which requires them to license the new products under similar terms of the original research with adequate credits to the original author.

CC-BY ND (Attribution No Derivatives): This license allows the users to use and distribute the original data without any modifications while attributing it to the original authors.

Other combinations such as CC-BY NC SA and CC-BY NC ND are also used for various purposes.

There is nothing like a best licensing agreement. The license used depends on the situation and context. Even though most open access journals use CC-BY, some articles with photographs and related content are licensed under CC-BY NC to prevent other publishers from printing the original data. Pandemics like the COVID-19 require research articles related to the pandemic to be published under the public domain to make them freely accessible to the entire population and unrestricted distribution to combat the health emergency. Articles related to public health emergency are also indexed free of cost in databases like PubMed during the pandemic which is appreciable.

Table 1 Summary of various license agreements

\begin{tabular}{llll}
\hline License & $\begin{array}{l}\text { Attribution } \\
\text { required }\end{array}$ & $\begin{array}{l}\text { Modifications } \\
\text { can be done? }\end{array}$ & $\begin{array}{l}\text { Commercial } \\
\text { purpose } \\
\text { usage }\end{array}$ \\
\hline CC0 & No & Yes & Yes \\
CC-BY & Yes & Yes & Yes \\
CC-BY SA & Yes & Yes & Yes \\
CC-BY NC & Yes & Yes & No \\
CC-BY ND & Yes & No & Yes \\
CC-BY NC SA & Yes & Yes & No \\
CC-BY NC ND & Yes & No & No \\
\hline
\end{tabular}


To conclude, researchers should be aware and vigilant while signing the licensing agreement with the journals in order to prevent misuse of their original works as well as to avoid unnecessary litigations. The authors should note that all authors from the countries which signed the Berne convention retain at least their moral rights for a minimum period of 50 years after their death [1].

Warm Regards,

\section{Declarations}

Conflict of Interest The authors declare no competing interests.

\section{References}

1. Morrison H, Desautels L (2016) Open access, copyright and licensing: basics for open access publishers. J Orthop Case Rep 6(1):1-2. https://doi.org/10.13107/jocr.2250-0685.360
2. Hrynaszkiewicz I, Cockerill MJ (2012) Open by default: a proposed copyright license and waiver agreement for open access research and data in peer-reviewed journals. BMC Res Notes 5:494. https://doi.org/10.1186/1756-0500-5-494

3. Favre J, Germond T, Clavert P, Collin P, Michelet A, Lädermann A (2020) Want a better h-index? - All you need to know about copyright and open access. Orthop Traumatol Surg Res 106(8):1475-1480. https://doi.org/10.1016/j.otsr.2020.05.015

Publisher's Note Springer Nature remains neutral with regard to jurisdictional claims in published maps and institutional affiliations. 